\title{
An Experimental Study on Coal Fines Migration during Single Phase Water Flow
}

\author{
Wenlong Han $\mathbb{D},{ }^{1}$ Yanbin Wang $\mathbb{D}^{1},{ }^{1}$ Jingjing Fan $\mathbb{D}^{\mathbb{D}},{ }^{2}$ Yong $\mathrm{Li}\left(\mathbb{D},{ }^{1}\right.$ Xiang $W u\left(\mathbb{D},{ }^{3}\right.$ \\ and Yun Yu iD ${ }^{1}$ \\ ${ }^{1}$ College of Geoscience and Surveying Engineering, China University of Mining and Technology, Beijing 100083, China \\ ${ }^{2}$ Research Institute of Petroleum Exploration and Development, Beijing 100083, China \\ ${ }^{3}$ China United Coalbed Methane Corporation Limited, Beijing 100016, China
}

Correspondence should be addressed to Yong Li; liyong@cumtb.edu.cn

Received 6 December 2019; Revised 30 June 2020; Accepted 10 July 2020; Published 14 August 2020

Academic Editor: Andrea Brogi

Copyright (C) 2020 Wenlong Han et al. This is an open access article distributed under the Creative Commons Attribution License, which permits unrestricted use, distribution, and reproduction in any medium, provided the original work is properly cited.

\begin{abstract}
Coal fines migration and intrusion in coal fractures affect coalbed methane (CBM) wells performance by reducing reservoir permeability and production continuity. Physical simulations are conducted to investigate the permeability variation under different diameter coal fines intrusion at various flow velocities and confining pressures. The results show that the conductivity of fractures is dramatically reduced and hardly recover to its initial condition after coal fines intrusion. The permeability after coal fines intrusion $\left(\mathrm{P}_{\mathrm{cfi}}\right)$ has no direct correlation with the increase of flooding velocity, while decreases with the increase of confining pressures. The fractures can be totally blocked by coal fines, while penetration also happened during the flooding process, causing permeability fluctuation. The permeability loss rates value for $80-120$ mesh coal fines intrusion are generally $<60 \%$ compared with the initial permeability, including the flow velocity of $2,3,4,6,8$, and $10 \mathrm{~mL} / \mathrm{min}$ with confining pressure of $6 \mathrm{MPa}$ and the confining pressure of $2,3,4,5$, and $6 \mathrm{MPa}$ with flow velocity of $3 \mathrm{~mL} / \mathrm{min}$. However, under $120+$ mesh coal fines condition, the permeability loss rates are higher than $85 \%$ under most flow velocities and confining pressures. When coal fines become smaller, the permeability loss rates decrease to be lower than $45 \%$, and part the coal fines are discharged with the water flow. Thus, coal fines proper dischargement can partly maintain the reservoir permeability during coalbed methane production. The results would be useful in understanding coal fines intrusion behaviors and its controlling strategies during CBM drainage.
\end{abstract}

\section{Introduction}

Coal is easily to be broken into pieces due to its brittle, lowstrength, and weakly consolidated nature [1-3]. Large amounts of coal fines generated during the tectonic evolution history, as well as the coalbed methane (CBM) production process of well drilling, completion, and hydraulic fracturing $[4,5]$. Coal fines can block cleats and hydraulic fractures, leading to the severe reduction in fracture permeability $[6,7]$. Further, coal fines occurrence can influence drainage continuity, causing dramatic borehole pressure fluctuations, and gas and water flow interruptions [8]. Coal fines blockage can also affect the spreading of pressure decreasing funnel and the gas production performance $[9,10]$. Controlling the stable output of coal fines is important for CBM wells production $[11,12]$.
The production of coal fines is related to a variety of engineering and geological factors, e.g., well type, drilling technology, completion technology, production system, coal mechanical strength, and its structural background $[13,14]$. Coal fines can be classified based on their genetic type as primary coal fines controlled by a variety of geological factors and secondary coal fines formed by engineering factors. Primary coal fines are generally shown as moniliform and bedded occurrences and are generally being found along fault planes and sliding layers (Figure 1) $[15,16]$. The primary coal fines are general smaller than $1 \mathrm{~mm}$ in diameter as particle friction can be happened during the tectonic movement $[17,18]$. The primary coal fines can be transported and output under suitable water flow velocity in wide and wellconnected fractures $[19,20]$. However, if the fractures connectivity is complex, with narrow throat and tough surfaces, 


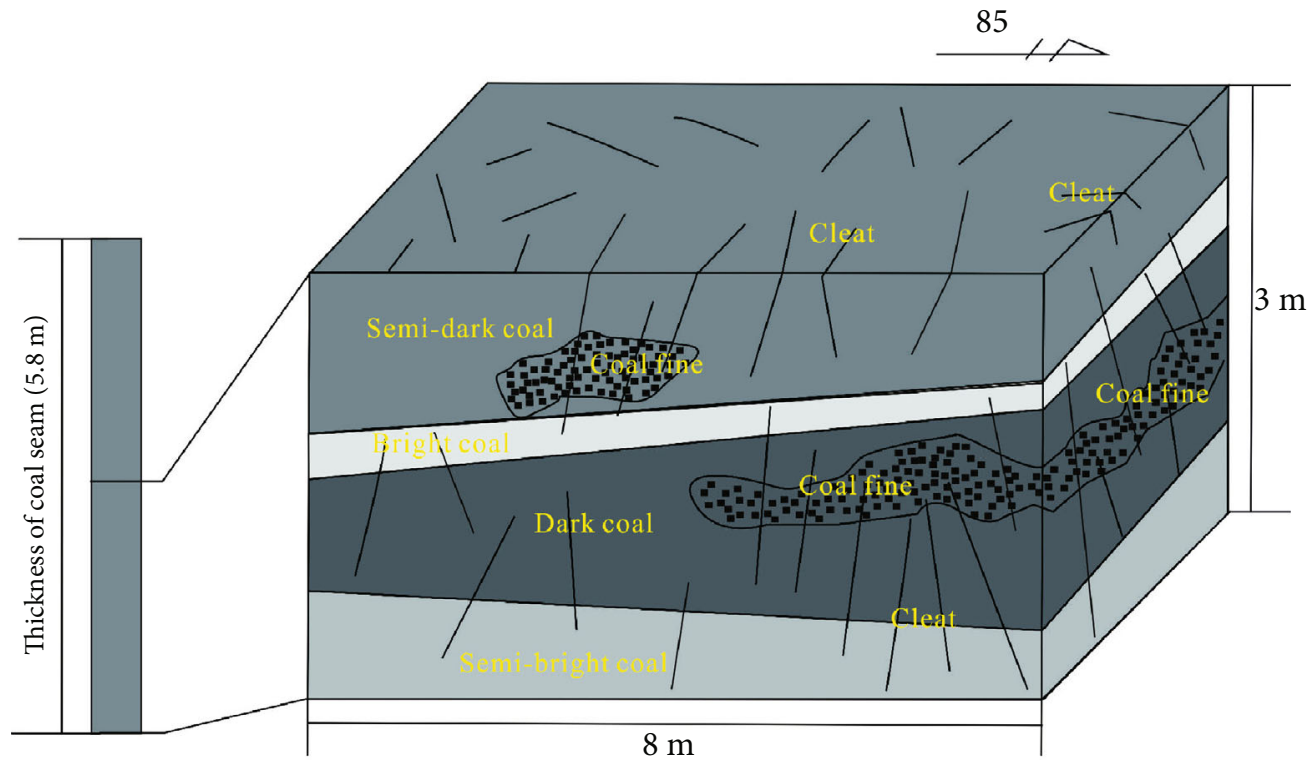

(a)

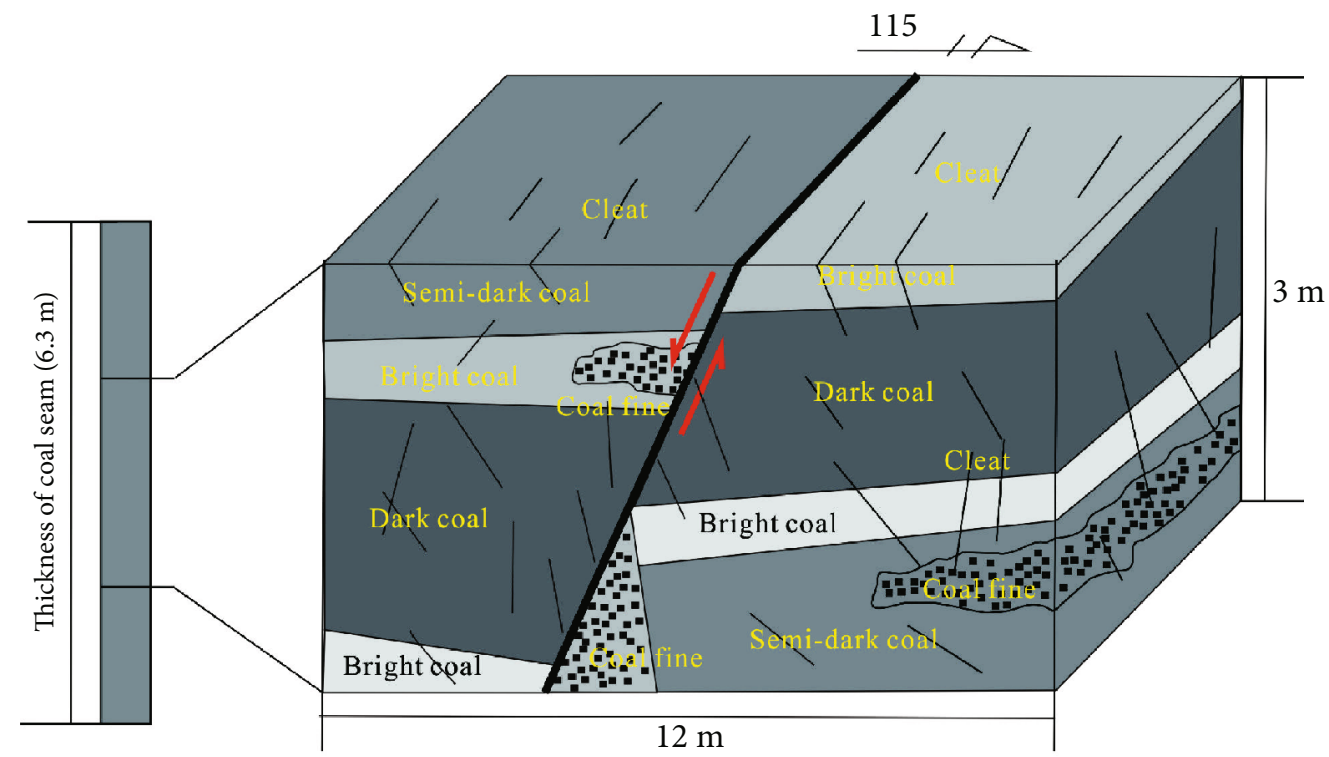

(b)

FIgURE 1: Diagram of the typical coal fines assemblage and morphology. (a) Diagram of the typical coal fines assemblage and morphology in coal seam \#3 in the southern Qinshui Basin. (b) Diagram of the coal fines assemblage and morphology in a typical fault zone in coal seam \#3 in the southern Qinshui Basin (Zhao et al. 2016).

TABLE 1: Properties of coal samples at the study site.

\begin{tabular}{lcccccccc}
\hline \multirow{2}{*}{ Number } & \multirow{2}{*}{$R_{\mathrm{o}, \max } / \%$} & \multicolumn{2}{c}{ Proximate analysis (wt\%, air dry basis) } & \multicolumn{3}{c}{ Coal composition (vol\%) } \\
& & Moisture content & Ash yield & Volatile matter & Vitrinite & Inertinite & Liptinite & Mineral \\
\hline CP-5 & 2.88 & 2.18 & 6.67 & 8.58 & 73.03 & 15.10 & 4.90 & 6.97 \\
\hline
\end{tabular}

Notes: $R_{\mathrm{o} \text {, max }}$ the mean maximum reflectance values of vitrinite of coal sample.

the coal fines can block the fractures [21, 22]. The secondary coal fines are mainly found in the near-well zone and fracturing fractures, which are relatively easy to be transported and produced [11].

Experimental studies have been conducted to investigate the relationship between the flow velocity and coal fines out- put under the single-phase water flow $[23,24]$. The critical flow conditions of coal fines movement and transport mechanisms based on stress analysis have also been quantitatively explained [25]. Mathematical models, including the coal fines detachment, the velocity of fine particles migration, and the permeability variation were discussed $[8,26]$. 


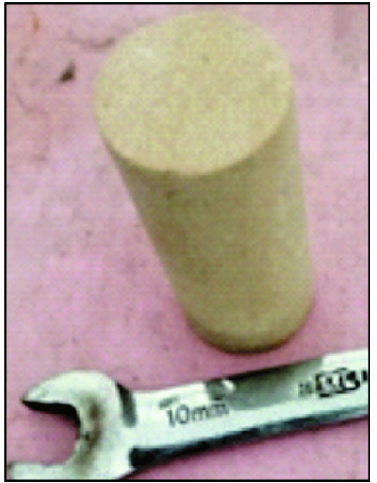

(a)

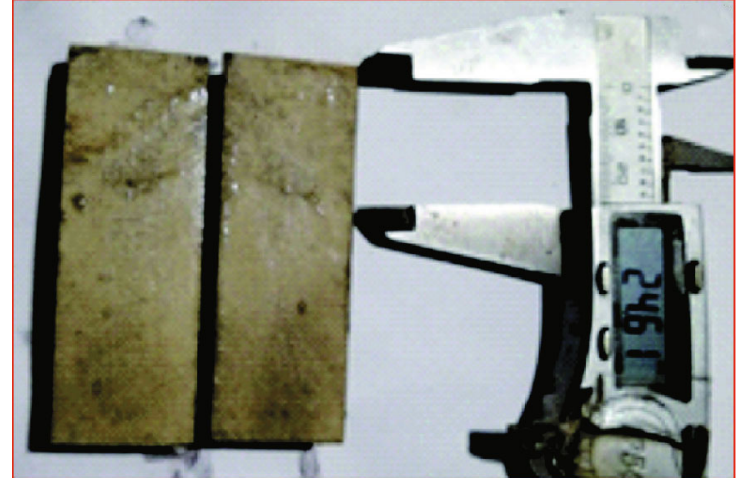

(b)

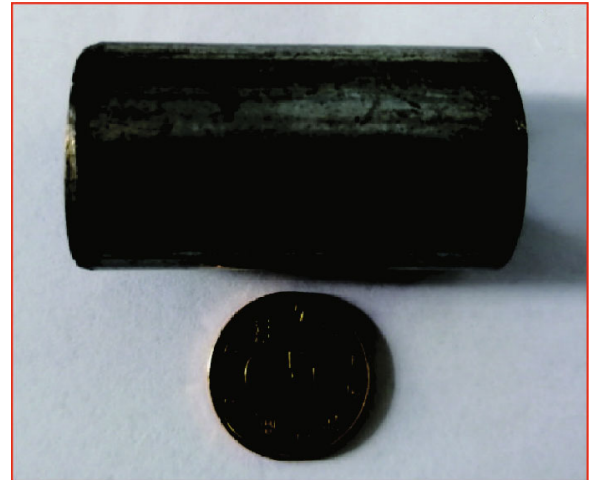

(c)

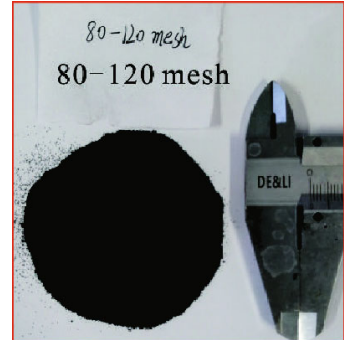

(d)

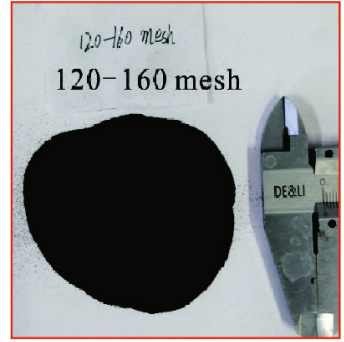

(e)

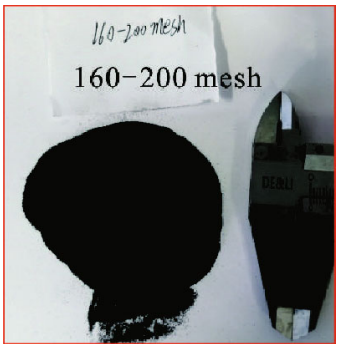

(f)

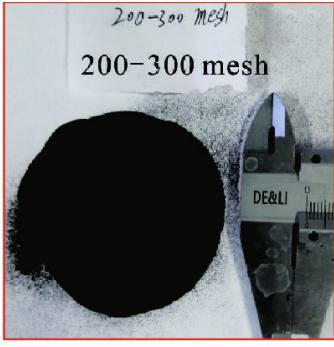

(g)

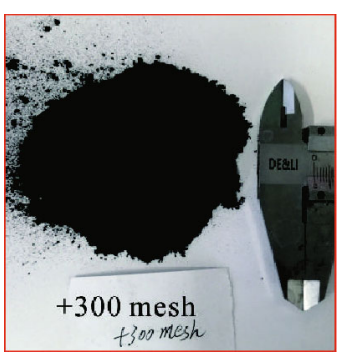

(h)

Figure 2: The material of coal fines intrusion experiments. (a) The sandstone sample. (b) The fractured sandstone samples. (c) The equipment of coal fines. $(\mathrm{d}-\mathrm{h})$ Coal fines of different mesh.

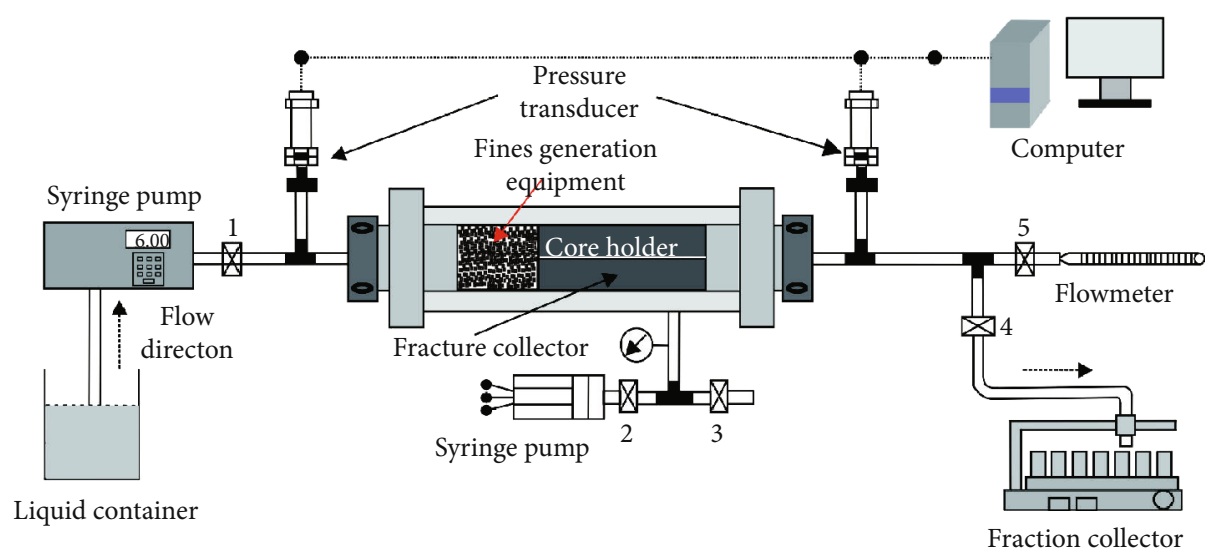

FIGURE 3: Schematic configuration of experimental apparatus for coal fines intrusion experiments.

Commercial software including ANSYS and FLUNET et al. were also adopted to simulate the migration of coal fines in the vertical and horizontal wellbores [7, 27].
Coal fines are not only be discharged into the wellbore but also invaded into the cleats and hydraulic fractures [28, 29]. According to the aforementioned brief literature review, 
TABLE 2: The coal fines intrusion experimental conditions of single-phase water flow displacement.

\begin{tabular}{lcc}
\hline Number & Coal fines size (mesh) & Experimental condition \\
\hline 1 & $/$ & Confining pressure: $6 \mathrm{MPa} ;$ \\
& & Flow velocity: $2,3,4,6,8,10 \mathrm{~mL} / \mathrm{min}$ \\
2 & $/$ & Confining pressure: $2,3,4,5,6 \mathrm{MPa} ;$ \\
& & Flow velocity: $3 \mathrm{~mL} / \mathrm{min}$ \\
3 & $80-120,120-160,160-200,200-300,300+$ & Confining pressure: $6 \mathrm{MPa} ;$ \\
4 & $80-120,120-160,160-200,200-300,300+$ & Flow velocity: $2,4,3,6,8,10 \mathrm{~mL} / \mathrm{min}$ \\
& & Confining pressure: $2,3,4,5,6 \mathrm{MPa} ;$ \\
\end{tabular}

TABle 3: Permeability of coal fines intrusion at different flow velocities.

\begin{tabular}{|c|c|c|c|c|c|c|}
\hline \multirow[b]{2}{*}{ Coal fines size (mesh) } & \multicolumn{6}{|c|}{ Flow velocity $(\mathrm{mL} / \mathrm{min})$} \\
\hline & 2 & 3 & $\begin{array}{c}4 \\
\text { Perm }\end{array}$ & $\begin{array}{c}6 \\
\left.\mu \mathrm{m}^{2}\right)\end{array}$ & 8 & 10 \\
\hline $80-120$ & 95.34 & 82.45 & 57.58 & 68.40 & 49.15 & 59.15 \\
\hline $120-160$ & 3.73 & 3.00 & 3.70 & 4.17 & 5.92 & 6.23 \\
\hline $160-200$ & 2.07 & 5.18 & 3.95 & 7.67 & 8.32 & 9.57 \\
\hline $200-300$ & 6.09 & 14.62 & 11.71 & 10.50 & 5.88 & 7.90 \\
\hline $300+$ & 2.23 & 3.82 & 2.04 & I & l & l \\
\hline
\end{tabular}

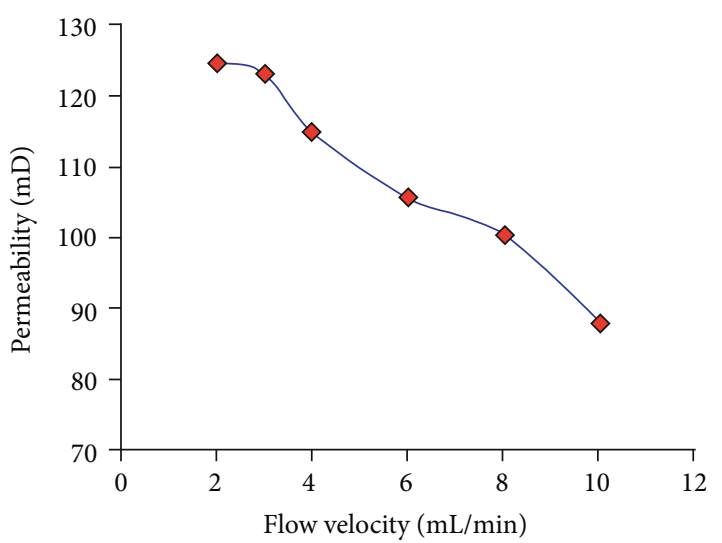

(a) Different flow velocity (confining pressure of $6 \mathrm{MPa}$ )

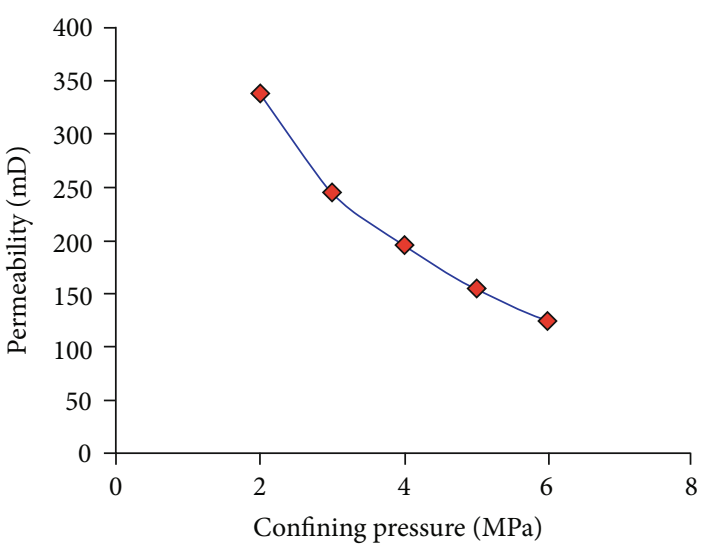

(b) Different confining pressure (flow velocity of $3 \mathrm{~mL} / \mathrm{min}$ )

FIGURE 4: Effect of flow velocity and confining pressure on permeability.

TABle 4: Permeability of coal fines intrusion at different confining pressure.

\begin{tabular}{|c|c|c|c|c|c|}
\hline \multirow{3}{*}{ Coal fines size (mesh) } & \multicolumn{5}{|c|}{ Confining pressure $(\mathrm{MPa})$} \\
\hline & 2 & 3 & 4 & 5 & 6 \\
\hline & \multicolumn{5}{|c|}{ Permeability $\left(10^{-3} \mu \mathrm{m}^{2}\right)$} \\
\hline $80-120$ & 270.49 & 139.80 & 102.83 & 64.14 & 82.45 \\
\hline $120-160$ & 29.21 & 17.80 & 11.62 & 4.24 & 3.00 \\
\hline $160-200$ & 78.25 & 21.49 & 2.94 & 4.84 & 5.21 \\
\hline $200-300$ & 20.91 & 24.69 & 21.60 & 26.59 & 15.05 \\
\hline $300+$ & 180.79 & 218.26 & 4.06 & 1.76 & 3.82 \\
\hline
\end{tabular}

previous studies mainly focused on the origin, composition, production mechanism, output, and transport mechanisms of coal fines. However, the characteristics of permeability

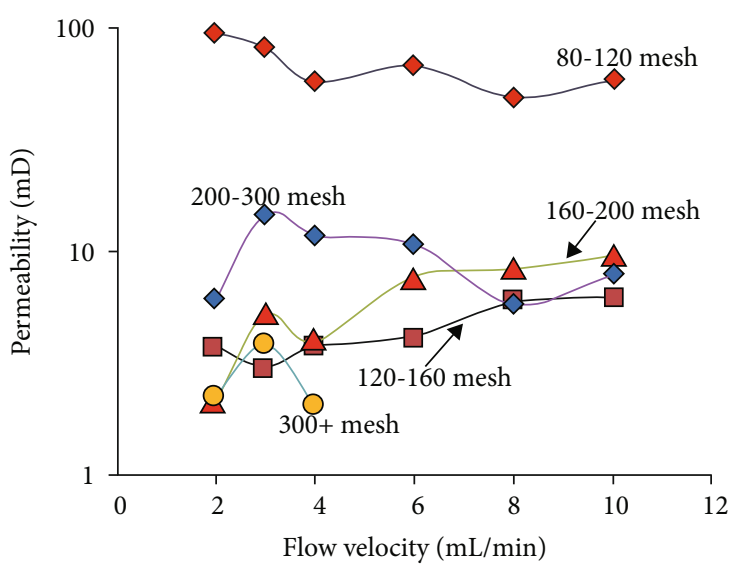

FIGURE 5: Effect of flow velocity and coal fines size on permeability. 


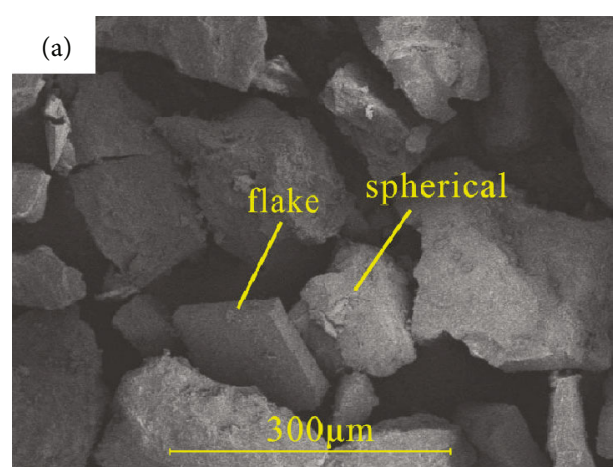

(a)

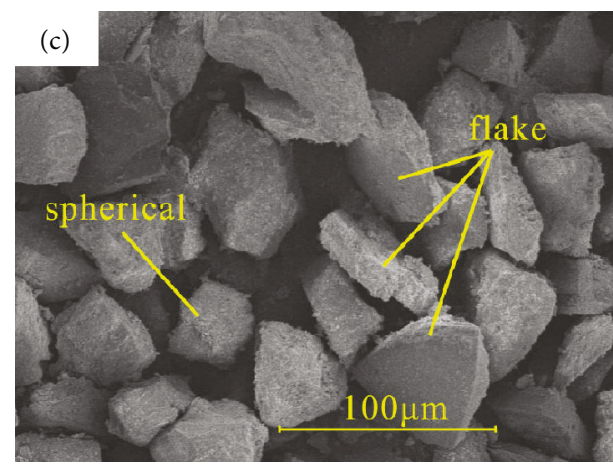

(c)

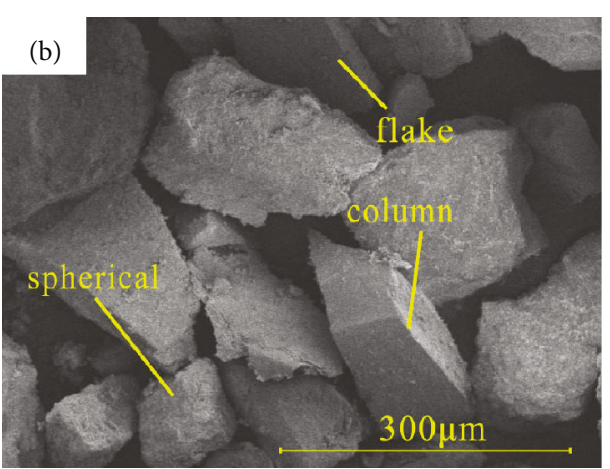

(b)

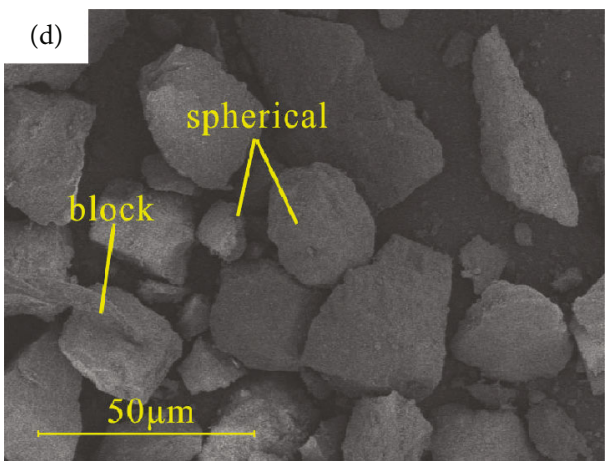

(d)

Figure 6: The morphology characteristic of coal fines by FE-SEM.

changes caused by coal fines intrusion and migration in fractures have not been revealed. In this study, we used selfdesigned coal fines intrusion instrument to study the variation of permeability under different coal fines intrusion conditions with different flow velocity and confining pressures. The variation of permeability after coal fines intrusion $\left(\mathrm{P}_{\mathrm{cfi}}\right)$ and its controlling factors were analyzed. Further, the permeability loss rates are calculated with the damage mechanisms of coal fines intrusion being discussed. The results can provide theoretical guidance for minimizing coal fines damage and managing CBM production. But the characteristics of permeability changes caused by coal fines intrusion and migration in the stage of two-phase gas and water have not been conducted, which is the limitations of the proposed research.

\section{Materials and Methods}

2.1. Sample Preparation. The experimental coal samples were collected from the Permian Shanxi Formation in the Changping Coal Mine in the southern Qinshui basin, China. Table 1 lists the basic coal property parameters of coal fines used, including the proximate analysis, maceral analysis, and maximum vitrinite reflectance. Proximate analyses were tested according to the ASTM D3172-13 international standards. The maximum vitrinite reflectance $\left(R_{\mathrm{o}, \max }\right)$ was tested following the ASTM D388-15 international standard. The coal samples were crushed into solid powders by grinder. The powdered coal samples were sieved into different particle size ranges by sifters of $80,120,160,200$, and 300 mesh.
Field emission scanning electron microscope (FE-SEM) was conducted to observe the micromorphologies of the coal fines. The Helios NanoLab 650 FEI SEM (Thermo Fisher Scientific, Waltham, MA, USA) at Beijing Center for Physical and Chemical Analysis, China, was used. The accelerating voltages were $1-10 \mathrm{kV}$. The working distances from detector to samples were 3-7 $\mathrm{mm}$ in this FE-SEM system.

Due to the poor mechanical properties of coal, new fractures are easy to be generated under repeated loading, influencing results accuracy. Sandstones are of relatively strong mechanical properties, and the tight sandstones are also of low permeability as coal. Thus, tight sandstones were selected as similar materials to test the coal fines intrusion and flow properties. The sandstone cores were drilled from the coal-bearing strata (Permian Shanxi Formation). Cylindrical sample $(7.99 \mathrm{~cm}$ in length, $2.55 \mathrm{~cm}$ in diameter, initially permeability of $9.18 \mathrm{mD}$ ) was cut into two pieces in the middle to simulate macroscopic cracks and fractures (Figures 2(a) and 2(b)).

2.2. Apparatus. The experimental apparatus (Figure 3) is composed of driving pump, core holder, fines generation equipment (Figure $2(\mathrm{c})$ ), pressure transducers, waste liquid collector, and data acquisition system (MCGS). The driving pump (ISCO 1000D syringe pump with maximum flow velocity of $10 \mathrm{~mL} / \mathrm{min}$ ) was utilized to inject distilled water at constant flow velocities. The injection pressure was continuously measured by piezometer A (range of measurement is $0-10 \mathrm{MPa}$ ) installed in the inlet of the core holder. The piezometer B (range of measurement is $0-2 \mathrm{MPa}$ ) was installed 


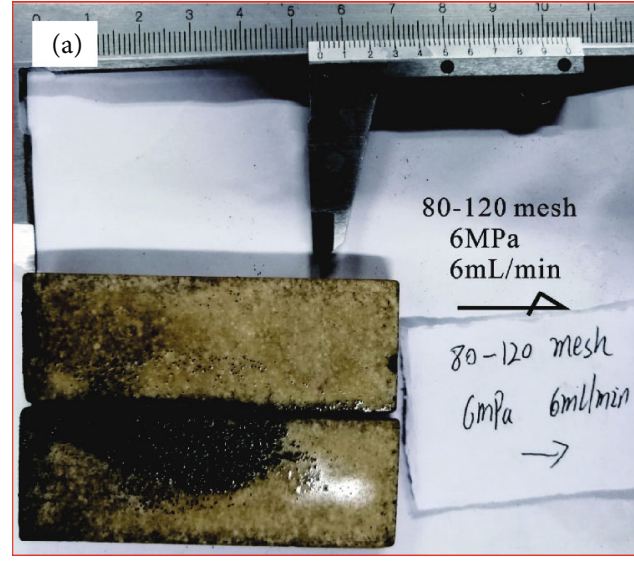

(a)

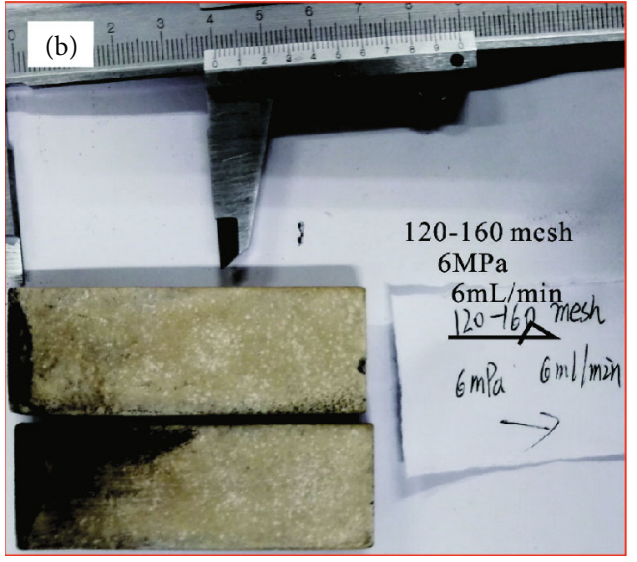

(b)

Figure 7: The characteristic of coal fines intrusion under different coal fines size. (a) The condition: coal fines size of 80-120 mesh, flow velocity of $6 \mathrm{~mL} / \mathrm{min}$, and confining pressure of $6 \mathrm{MPa}$. (b) The condition: coal fines size of 120-160 mesh, flow velocity of $6 \mathrm{~mL} / \mathrm{min}$, and confining pressure of $6 \mathrm{MPa}$.

in the outlet of the core holder to measure the real-time outlet pressure. Confining pressures for the core holder was applied by the syringe pump (maximum pressure of $20 \mathrm{MPa}$ ). The fluid flow rate, injection pressure, and outlet pressure were recorded to calculate the permeability. The fine generation experiment was used to provide sufficient coal fines with the water flows invading into the fractures. The MCGS system developed by China University of Petroleum (Beijing) was used to transfer and digitize pressure measurements, and the data was displayed and recorded in real-time.

2.3. Procedures. Three variable parameters (flow velocity, confining pressure, and coal fines size) were analyzed to reveal the intrusion and migration of coal fines in the fractures. Four series of experiment were conducted (Table 2): (1) original cores without fines intrusion under different flow velocity and constant confining pressure; (2) original cores without fines intrusion under different confining pressure and constant flow velocity; (3) different sizes fines intrusion with different flow velocities and constant confining pressure; (4) different sizes fines intrusion with different confining pressures and constant flow velocities. Every experiment was sustained for 120 mins after the outlet flow velocity being stable.

2.4. Permeability Calculation. In each set of core flooding experiments, the permeability was calculated by Equation (1).

$$
k=\frac{Q \mu L}{A\left(P_{1}-P_{2}\right)} \times 10^{3},
$$

where $k$ is permeability, $\mathrm{mD} ; P_{1}$ is inlet pressure, $10^{-1} \mathrm{MPa} ; P_{2}$ is outlet pressure, $10^{-1} \mathrm{MPa} ; \mu$ is the absolute viscosity of fluid, $\mathrm{mPa} \cdot \mathrm{s} ; A$ is the sectional area of the sand core, $\mathrm{cm}^{2} ; L$ is the length of the sand core, $\mathrm{cm}$;

2.5. Permeability Loss Rate. Due to the difference of initial permeability under different flow velocity and confining

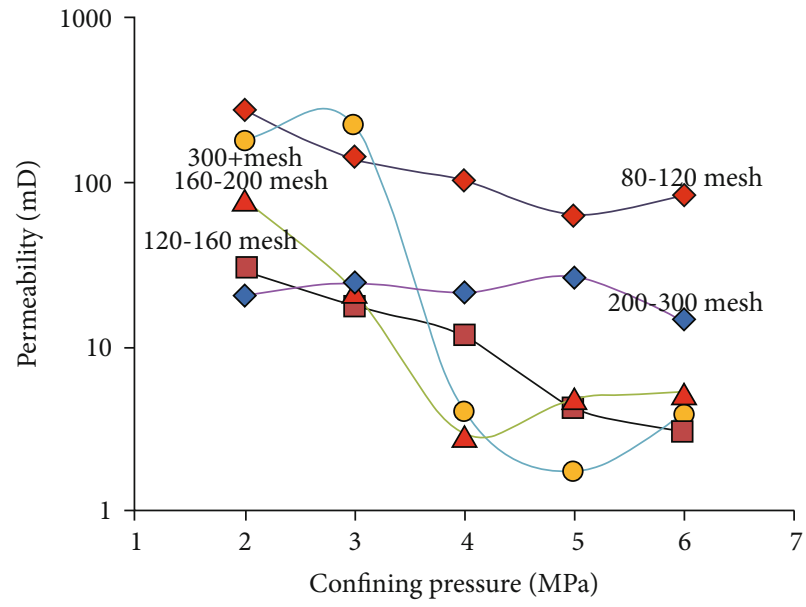

FIgURE 8: Effect of confining pressure and coal fines size on permeability.

pressures, the loss rate of permeability was introduced and calculated by Equation (2).

$$
D_{z i j}=\frac{\left|k_{z i j}-k_{i j}\right|}{k_{i j}} \times 100 \%,
$$

where $D_{i}$ is the loss rate of the permeability, $\%$; $k_{i j}$ is the initial permeability under different flow velocities and confining pressures, $\mathrm{mD} ; K_{z i j}$ is the $\mathrm{P}_{c f i}$ under different flow velocity and confining pressure conditions, $\mathrm{mD}$.

\section{Results}

3.1. Properties of Coal Fine Samples. Table 1 shows the microscopic composition quantitative analyses of coal fine samples by polarizing microscope. The average maximum vitrinite reflectance $\left(R_{\mathrm{o} \text {, max }}\right)$ of the samples was $2.88 \%$, indicating that the coals are of high maturity stage [30]. The organic macerals of the samples were mainly vitrinite, followed by 


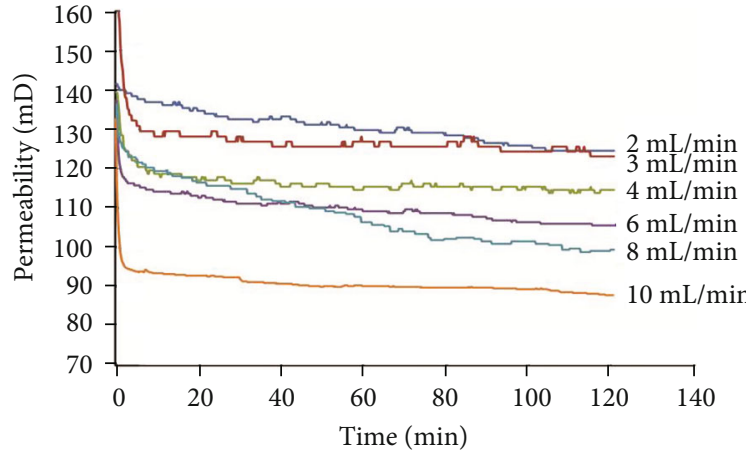

(a) No coal fines intrusion

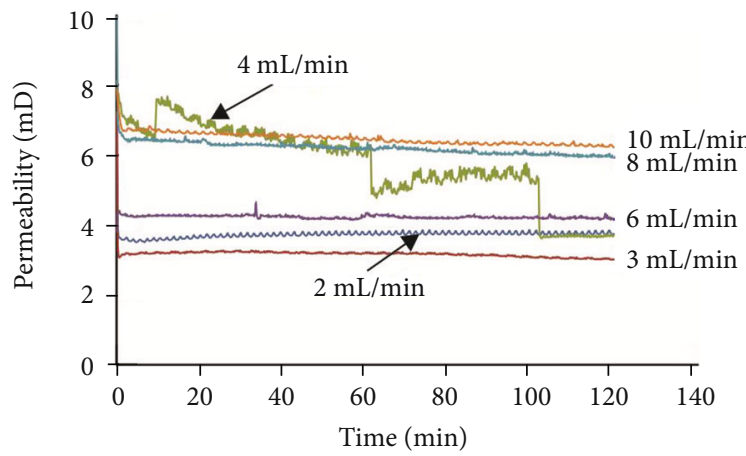

(c) $120-160$ mesh

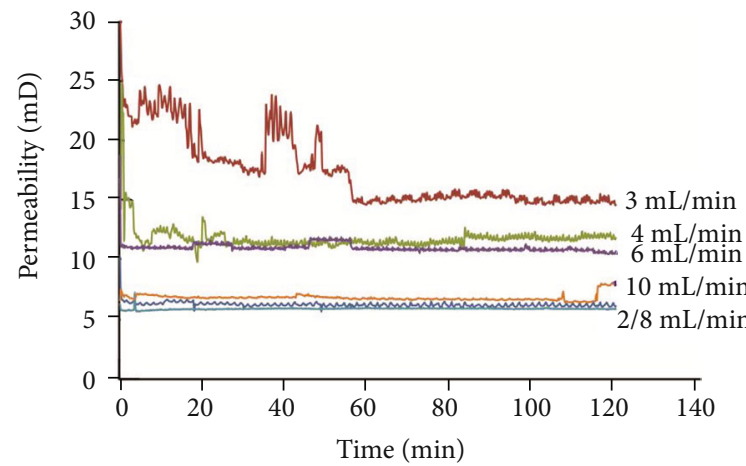

(e) 200-300 mesh

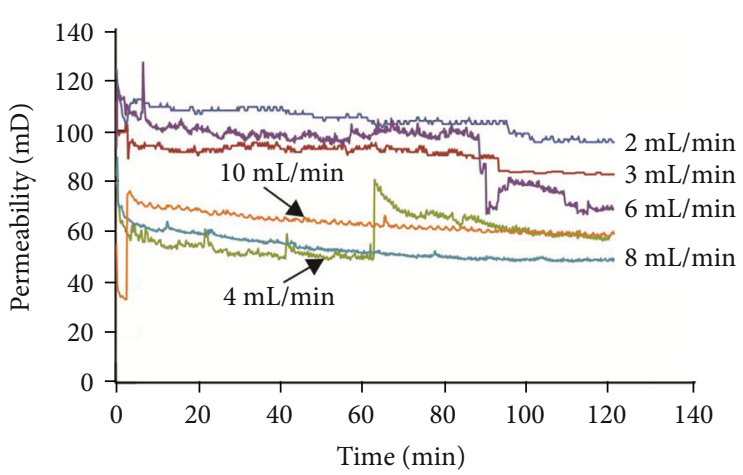

(b) 80-120 mesh

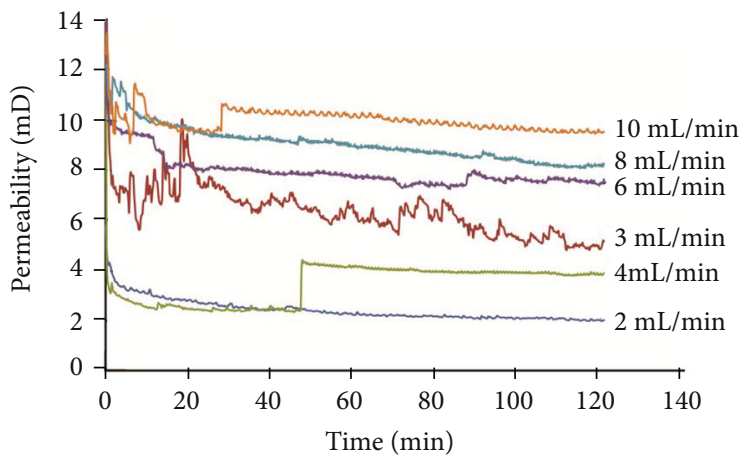

(d) 160-200 mesh

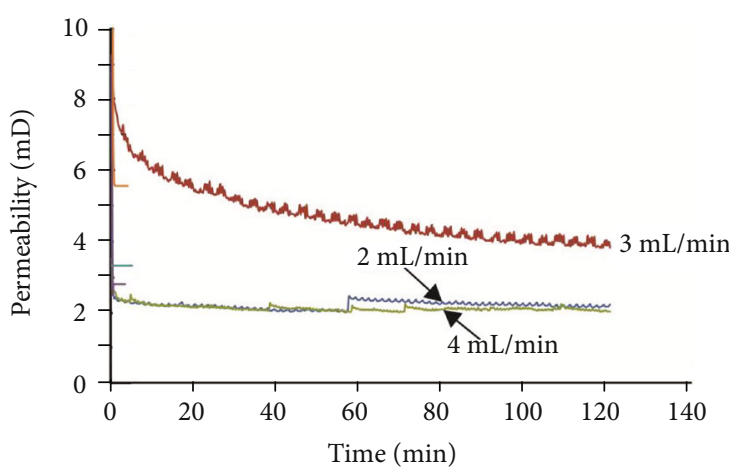

(f) $300+$ mesh

FIGURE 9: Permeability evolution under different flow velocity (confining pressure of $6 \mathrm{MPa}$ ).

inertinite. Furthermore, the proximate analysis of the samples indicates that the contents of moisture, ash, and volatile under air-dry basis are $2.18 \%, 6.67 \%$ and $8.58 \%$, respectively. The maximum vitrinite reflectance $\left(R_{\mathrm{o}, \max }\right)$ of all the samples ranges from $1.23 \%$ to $1.75 \%$.

\subsection{Permeability of Coal Fine Intrusion under Different Flow} Velocity and Confining Pressures. The permeability variation with no coal fine intrusion, at different flow velocities under $6 \mathrm{MPa}$ confining pressure was plotted in Table 3 . The permeability of the flow velocity of $2,3,4,6,8$, and $10 \mathrm{~mL} / \mathrm{min}$ are $124.41,122.97,114.63,105.41,100.29$, and $87.86 \mathrm{mD}$, respectively. As water flow velocity increases, the permeability decreases (Figure 4(a)), similar to commonly known flooding experiment $[31,32]$. When the flow velocity is less than $3 \mathrm{~mL} / \mathrm{min}$, the permeability shows no variations. Thus, the fluid velocity sensitivity has a critical flow velocity (Figure 4(a)), which is obvious when water flow $<3 \mathrm{~mL} / \mathrm{min}$, while the permeability decreases obviously when the flow velocity is higher than $3 \mathrm{~mL} / \mathrm{min}$.

Permeability differences at different confining pressures were tested with a flow velocity of $3 \mathrm{~mL} / \mathrm{min}$. The permeability of the confining pressure of $2,3,4,5$, and $6 \mathrm{MPa}$ is $336.28,243.97,194.41,152.87$, and $122.97 \mathrm{mD}$, respectively (Table 4). The permeability decreases with the increase of confining pressures, even though the variation rate decreases with the increase of confining pressure [33], suggesting the fractures closure gradually weakened [34] (Figure 4(b)).

3.3. $P_{c f i}$ Under Different Flow Velocity and Confining Pressure. During the experiment, the coal fines can easily flow through the fines generation equipment and invade into the fractures. 


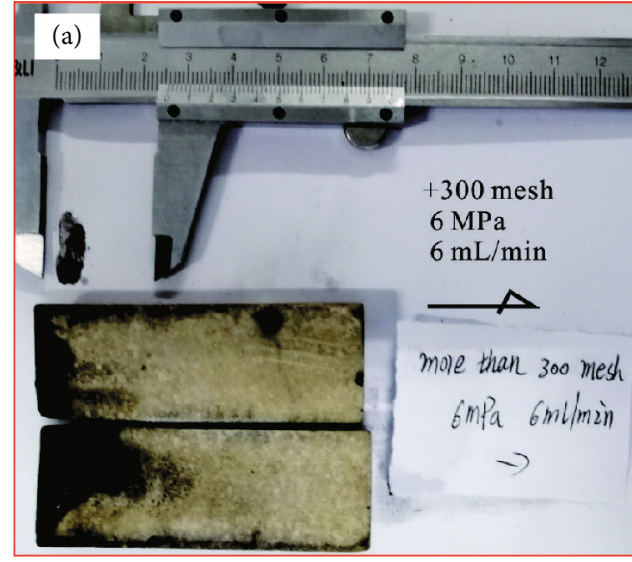

(a)

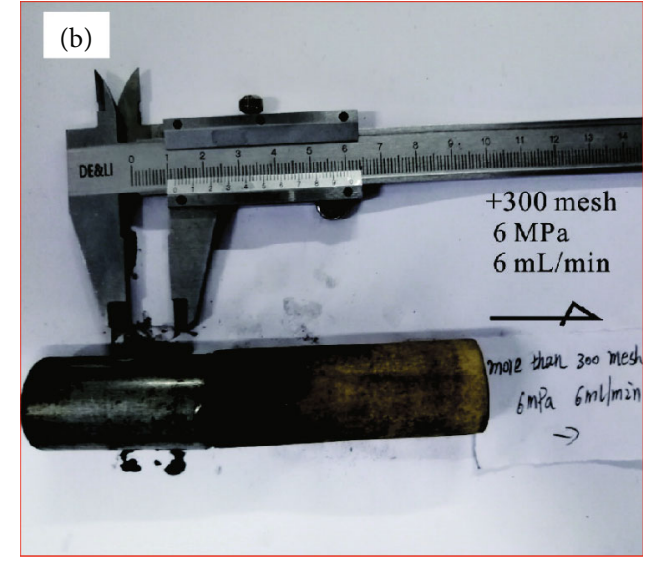

(b)

Figure 10: The characteristic of coal fines intrusion at 300+ mesh, $6 \mathrm{~mL} / \mathrm{min}$, and $6 \mathrm{MPa}$. (a) The characteristic of coal fines intrusion. (b) The characteristic of coal fines adhesion.

Table 3 lists the coal fines invasion permeability at different flow velocities under the confining pressure of $6 \mathrm{MPa}$. All the $\mathrm{P}_{\text {cfi }}$ values of 80-120 mesh coal fines are higher than $49 \mathrm{mD}$. The $\mathrm{P}_{\text {cfi }}$ with particles of 200-300 mesh is higher than $9.18 \mathrm{mD}$ at the flow velocity condition of 3,4 , and $6 \mathrm{~mL} / \mathrm{min}$. $\mathrm{P}_{\mathrm{cfi}}$ values under other conditions are generally lower than $9.18 \mathrm{mD}$. Coal fines of $80-120$ mesh show less damage to the cores permeability.

The $\mathrm{P}_{\text {cfi }}$ values under different confining pressures with $3 \mathrm{~mL} / \mathrm{min}$ flow velocities were recorded in Table 4 . The $\mathrm{P}_{\text {cfi }}$ with $80-120$ mesh coal fines is higher than $270 \mathrm{mD}$ under the confining pressure of $2 \mathrm{MPa}$. The permeability with 300 + mesh coal fines intrusion is approximately $200 \mathrm{mD}$ under confining pressures of 2 and $3 \mathrm{MPa}$. The permeability is higher than $60 \mathrm{mD}$ with 80-120 mesh coal fines in the confining pressure of $3,4,5$, and $6 \mathrm{MPa}$ and 160-200 mesh fines in the confining pressure of $2 \mathrm{MPa}$. Other $\mathrm{P}_{c f i}$ values are less than $20 \mathrm{mD}$ under the flow velocities is $3 \mathrm{~mL} / \mathrm{min}$. Thus, the confining pressure and particle size both affect the permeability variation, and under certain circumstances, e.g., smaller coal fines and lower confining pressures, the permeability damage rate is low.

3.4. Flow Velocity Influences on $P_{c f i}$. Figure 5 illustrates that the $\mathrm{P}_{\text {cfi }}$ variation with the increases of flow velocity from 2 to $10 \mathrm{~mL} / \mathrm{min}$. As coal fines of $120-160$ and $160-200$ mesh, the $\mathrm{P}_{\text {cfi }}$ shows an increasing trend. The $\mathrm{P}_{\text {cfi }}$ variation of 80 120 mesh shows a decline trend, while 200-300 mesh shows increased and then decrease trend. Comparing the variation curves of initial permeability (Figure 4 ) and $\mathrm{P}_{\text {cfi, }}$ it can be seen that not all the $\mathrm{P}_{\mathrm{cfi}}$ curves show a monotonous decline. This result is influenced by three aspects. Firstly, the coal fines are invaded into the fractures freely. However, no boundaries are clearly settled on the edge of the cores [35]. Thus, the quantity and degree of coal fines intrusion has a randomness. And the damage degree to fractures is not constant. Secondly, the morphology of coal fines particles observed by FE-SEM is flake, column, block, and spherical (Figure 6). The difference of coal fines particles morphology has different occurrence characteristics in the fractures, thus different damage to the fractures [36]. Additionally, the movement forms of coal fines include shifting, suspension, and neutral suspension, which are influenced by many factors, including material composition, morphology, fluid properties, and stress characteristics [37]. The neutral suspension movement is not considered in the experiment, because it only exists the condition of laminar flow state and low turbulence intensity [37]. As the flow rate increases, the turbulence intensity increases, which causes the suspension moving of coal fines. The amount of suspension is controlled by the turbulent intensity, which strengthens the randomness of invasion.

The $\mathrm{P}_{\mathrm{cfi}}$ variation with the coal fines size increases does not show a fixed trend at the same flow velocity. Coal fines can be transported by single particle or agglomerate particles; thus, the amount of invaded coal fines shows no clear relationship with particle size [36]. Further, the difference in coal fines shape causes different permeability damage. The lager coal fines of flake and thin layer shape can also invade further into the fractures, leading serious damage to permeability (Figure 7). Therefore, the variation of $\mathrm{P}_{c f i}$ is irregular at the same flow velocity.

3.5. Confining Pressure Influences on $P_{c f i}$. The $\mathrm{P}_{c f i}$ values decrease with the increases of confining pressure at the flow velocity of $3 \mathrm{~mL} / \mathrm{min}$ (Figure 8). For coal fines of $80-120$ mesh, the $\mathrm{P}_{\mathrm{cfi}}$ shows a decrease and then increased trend. The $\mathrm{P}_{\text {cfi }}$ variation for 120-160 mesh coal fines shows a monotonous decline trend, and the 160-200 mesh and 300+ mesh fines show a slight increase after a sharp decrease. The variation curve of 200-300 mesh fines remains steady during the whole experiment process. The above is caused by the both influences of confining pressure and fines intrusion. The variation of $\mathrm{P}_{\text {cfi }}$ with confining pressures can be divided into two stages. When the confining pressure is lower than $4 \mathrm{MPa}$, the $\mathrm{P}_{\text {cfi }}$ values are controlled by the effective stress and coal fines intrusion, showing a continuous decline with the confining pressure increases. When confining pressure is higher than $4 \mathrm{MPa}$, the $\mathrm{P}_{\text {cfi }}$ values are mainly controlled by coal fines intrusion, showing an irregular variation with confining pressure variation. Under high confining 


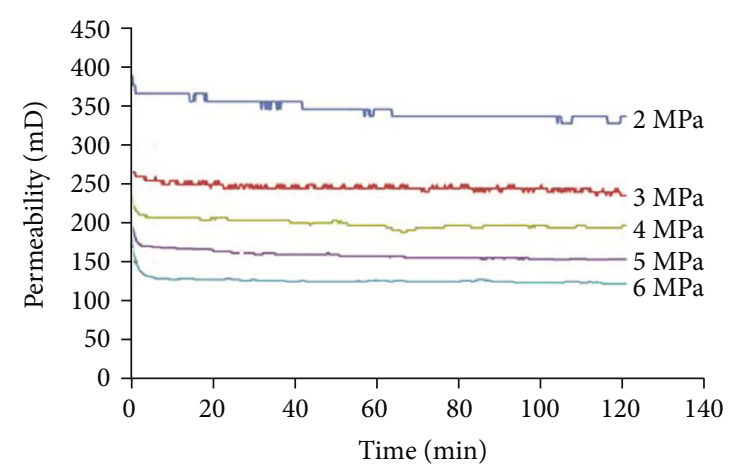

(a) No coal fines intrusion

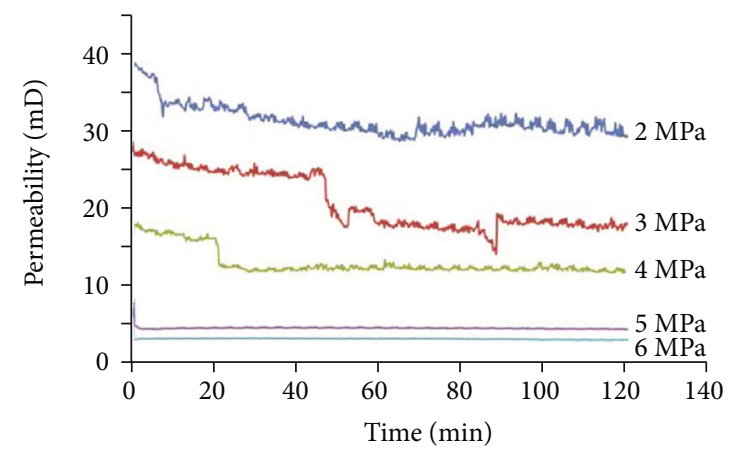

(c) $120-160$ mesh

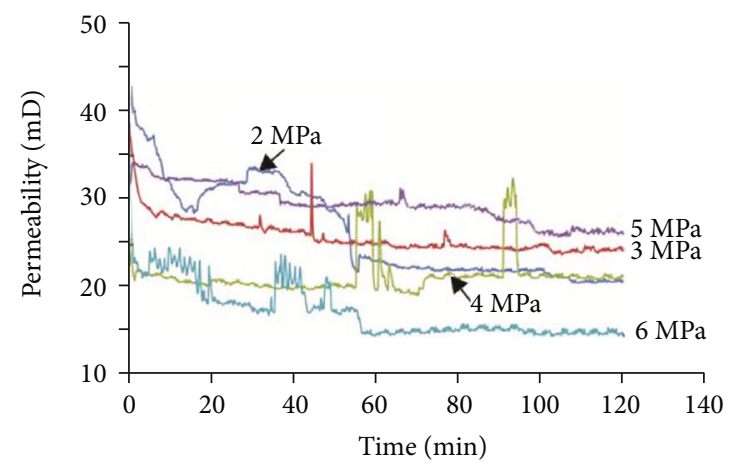

(e) 200-300 mesh

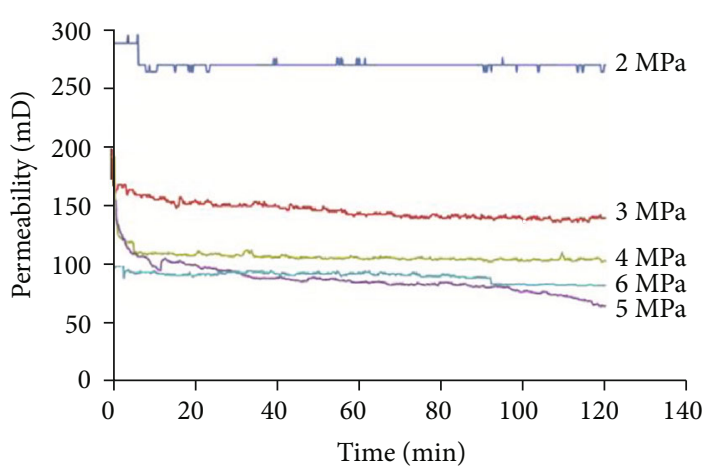

(b) 80-120 mesh

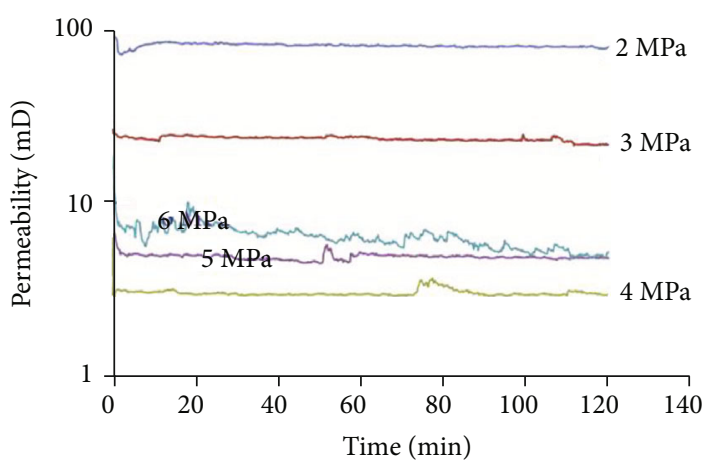

(d) 160-200 mesh

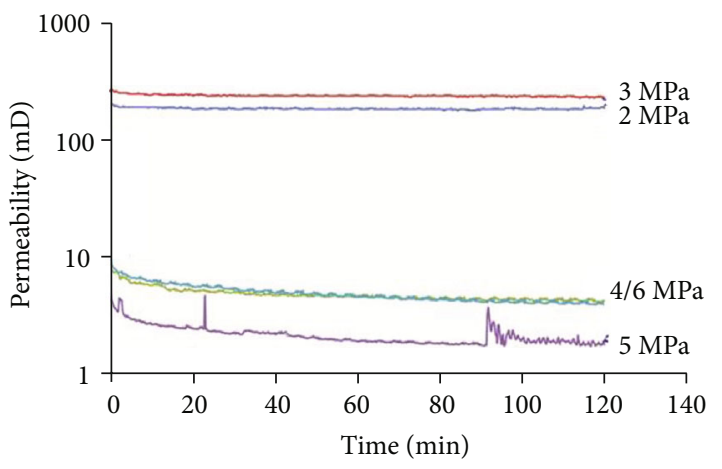

(f) $300+$ mesh

Figure 11: Permeability evolution under different confining pressure (flow velocity of $3 \mathrm{~mL} / \mathrm{min}$ ).

pressure conditions, the degree of fracture closure is high and the influence of effective stress is weakened [7,38]. The morphology and aggregations of coal fines lead to random intrusion and irregular variation of the $\mathrm{P}_{\mathrm{cfi}}$. Thus, even under the same confining pressures, the $\mathrm{P}_{\text {cfi }}$ values with different coal fines intrusion are irregular.

\section{Discussion}

4.1. $P_{c f i}$ Evolution under Different Flow Velocity. The coal fines can be captured by the fractures by the mechanisms of blocking, attachment, interception, diffusion, and sedimentation, which can trigger a remarkable permeability response [39]. Figure 9 shows that the permeability is rapidly declined as with coal fine transportation and intrusion. The coal fines blockage can cause abrupt permeability deterioration due to closure of fractures. The damage of fractures permeability under the coal fines transportation and intrusion is difficult to recovery during the experiment process (Figure 9). Thus, removing coal fines without changing the drainage intensity is impossible $[40,41]$. The $\mathrm{P}_{\text {cfi }}$ variation curves are more unstable than the permeability test curves without coal fines intrusion (Figure 9(a)). Water flow may break through part of the coal fines blocked in the fractures, but the coal fines can quickly saturate the fractures again. When the coal fines are smaller than 120 mesh, the final permeability remains above $50 \mathrm{mD}$ (Figure 9(b)). However, the final permeability only remains about $10 \mathrm{mD}$ with coal fines being bigger than 120 mesh (Figures 9(c)-9(f)).

The relationship between the $\mathrm{P}_{\mathrm{cfi}}$ values and the coal fines sizes indicates that the damage of permeability also has a critical particle size. The fines bigger than the critical value show less damage to permeability, while the smaller fines show more damages. Free coal fines are invaded into the fractures 


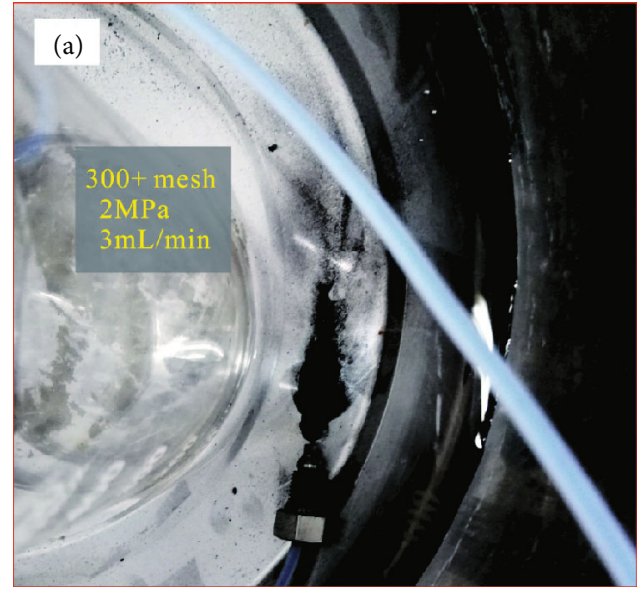

(a)

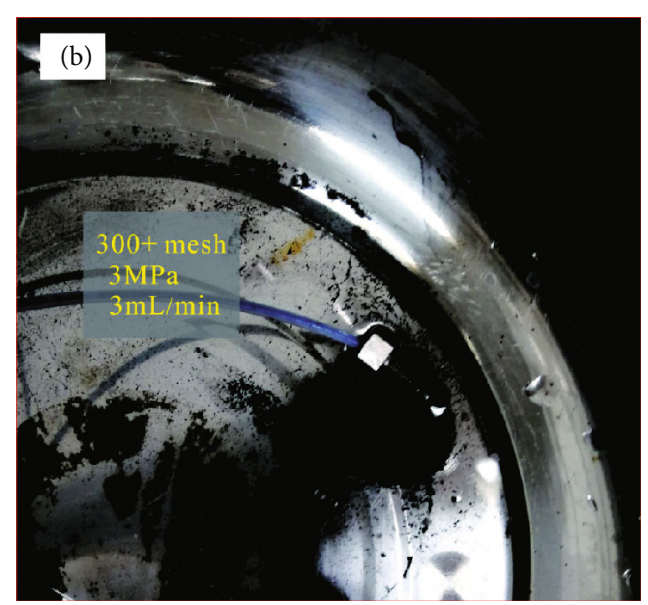

(b)

Figure 12: The phenomenon found coal fines output. (a) The condition: coal fines size of $+300 \mathrm{mesh}$, flow velocity of $3 \mathrm{~mL} / \mathrm{min}$, and confining pressure of $2 \mathrm{MPa}$. (b) The condition: coal fines size of $+300 \mathrm{mesh}$, flow velocity of $3 \mathrm{~mL} / \mathrm{min}$, and confining pressure of $3 \mathrm{MPa}$.

or attached to the edge of fractures with water flow; thus, the degree of blockage and the characteristic of coal fines decide the permeability variation. Larger particles (less than 120 mesh) are difficult to invade into the fractures, and most of them were only attached on the edge of fractures $[42,43]$. And for large particle size, the pores and throats between the particles are relatively bigger; thus, the degree of permeability damage is relatively weak. Smaller coal fines can easily invade into the fractures with the water flow. On the one hand, large amounts of small coal fines block the fractures, leading to serious permeability reduction or even totally loss of conductivity (Figures 9(d) and 9(e)). On the other hand, small coal fines can also block the fractures due to fine sedimentation and blockage in thin fractures (Figures 9(c) and $9(\mathrm{f})$ ). Low $\mathrm{P}_{\text {cfi }}$ values generally occur with stable variation curve (Figures 9(c)-9(f)). If the conductivity of fractures is totally lost, it is difficult to arouse the migration of the blocked coal fines under steady flow conditions $[40,41]$.

If the flow velocity is too fast, large amounts of coal fines will migrate and block the fractures quickly, leading to the decrease in permeability and increase in injection pressure [44] (Figure 9(f)). For coal fines of 300+ mesh, the injection pressures suddenly increase under the flow velocities $>6 \mathrm{~mL} / \mathrm{min}$, leading to experiment interruption. Small coal fines are also easy to move with water flow and invade into the fractures; thus, a large amount of coal fines can migrate into fractures with the increase in flow velocity [11, 45]. Thus, small coal fines are more conductive to aggregation and adhesion in the flow paths compared with large particles (Figure 6). Aggregations of coal fines also influence the fractures permeability, and the coal fines in the fractures may be compressed, causing porosity and permeability reduction with the increase of injection pressure [18] (Figure 10). Thus, during CBM wells drainage, the production pressure drop should be controlled within a certain range, avoiding coal fines extensive migration [32].

4.2. $P_{c f i}$ Evolution under Different Confining Pressure. The damage of fractures permeability under the coal fines trans- portation and intrusion is instantaneously, hardly can be recovered (Figure 11). The permeability variation curves under low confining pressures $(2,3$, and $4 \mathrm{MPa})$ are more unstable and wavier frequently than under the high confining pressures ( 5 and $6 \mathrm{MPa}$ ). The blocked coal fines receive little resistance and can easily be broken by the water flow under the low confining pressure, which can cause a temporary sharp increase in permeability. Then, new coal fines block the fractures again. Thus, the $\mathrm{P}_{\text {cfi }}$ test curves under high confining pressure show less fluctuation. For 80-120 mesh coal fines, the final permeability remains above $60 \mathrm{mD}$ (Figure 9(b)). As for 300+ mesh fines, the permeability shows differences under different confining pressures. The reason is that the small fines can be freely transported from the large width fractures under the less confining pressure $(2$ and $3 \mathrm{MPa})$. However, under high confine pressures, fines are hard to be migrated (Figure 12).

4.3. The Characteristic of Permeability Loss Rate. The permeability loss rate was quantitatively determined (Figure 13). Figure 13(a) shows the permeability loss rates variation with the flow velocity increases at the $6 \mathrm{MPa}$ confining pressure. For 80-120 mesh fines, the permeability loss rates are low, ranging from $20 \%$ to $50 \%$. The variation curve presents an "M" form with the flow velocity increase. For fines size smaller than 120 mesh, the permeability loss rates are more than $85 \%$. And the variation curves present a downward trend with the flow velocity increases. Figure 13(b) shows the permeability loss rates variation with the confining pressures increases at the flow velocity of $3 \mathrm{~mL} / \mathrm{min}$. For $80-120$ mesh fines, the permeability loss rates are also low (ranging from $15 \%$ to $60 \%$ ), and the variation curve presents a single-peak form. As for $300+$ mesh fines with the confining pressure of 3 and $2 \mathrm{MPa}$, the permeability loss rates are $2.64 \%$ and $44.75 \%$, respectively. However, under confining pressures of 4,5 , and $6 \mathrm{MPa}$, the permeability loss rates all increase over $90 \%$. Therefore, coal fines proper discharge can decrease the permeability loss within coal reservoirs $[31,46]$. The permeability loss rates of others are also higher 


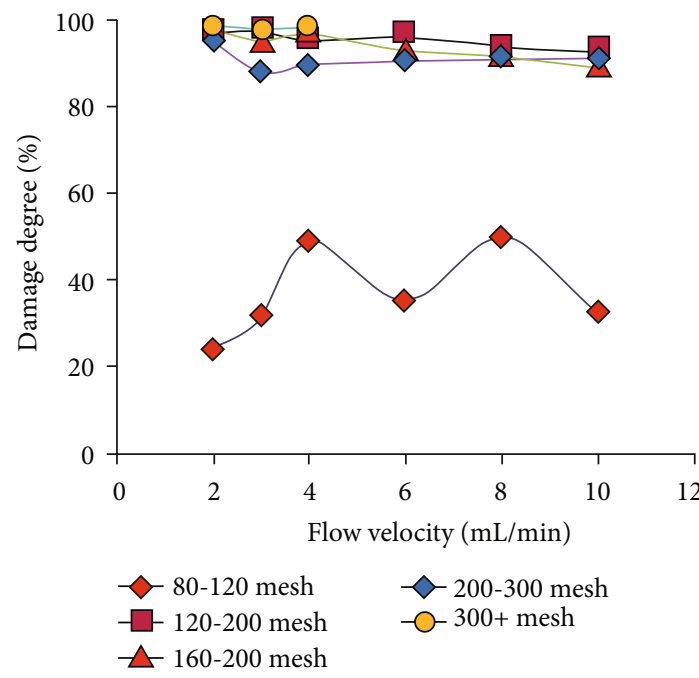

(a) Different flow velocity (confining pressure of $6 \mathrm{MPa}$ )

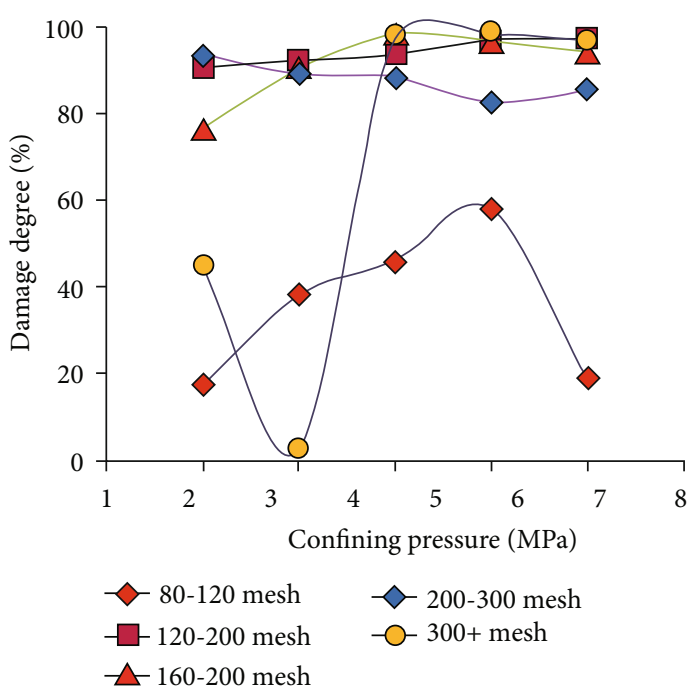

(b) Different confining pressure (flow velocity of $3 \mathrm{~mL} / \mathrm{min}$ )

FIgURe 13: Permeability loss rate at different condition.

than $80 \%$ except the $160-200$ mesh at $2 \mathrm{MPa}$. The results demonstrate that the coupling relationship of crack width and fines size both affects the permeability loss degree.

\section{Conclusions}

By simulating coal fines migration within fractures, factors including coal fines size, flow velocities, and confining pressures were discussed. The following conclusions can be conducted.

The permeability without coal fine intrusion decreases with the increase of flow velocity and confining pressure. The fluid velocity sensitivity has a critical flow velocity of $3 \mathrm{~mL} / \mathrm{min}$.

The conductivity of fractures decreases dramatically and hardly to be recovered with coal fines intrusion. The $\mathrm{P}_{\text {cfi }}$ value variation with flow velocities is irregular, while decreases with the increase of confining pressures. The $\mathrm{P}_{\text {cfi }}$ values are controlled by effective stress and coal fines intrusion together under low confining pressure and are mainly controlled by coal fines intrusion under high confining pressures. A significant amount of coal fines can quickly block the fractures under higher water flow velocities; thus, the bottom hole pressure drop should be controlled a certain range during CBM drainage.

The permeability loss rates are generally lower than $60 \%$ for 80-120 mesh coal fines intrusion, including flow velocity of $2,3,4,6,8$, and $10 \mathrm{~mL} / \mathrm{min}$ with confining pressure of $6 \mathrm{MPa}$, and $3 \mathrm{~mL} / \mathrm{min}$ under 3, 4, 5, and $6 \mathrm{MPa}$. However, under $120+$ mesh coal fines intrusion, the permeability loss rates are higher than $85 \%$ under most flow velocity and confining pressures. When coal fines becoming smaller, the permeability loss rate values (e.g., $300+$ mesh, less than $3 \mathrm{MPa}$ confining pressure, $3 \mathrm{~mL} / \mathrm{min}$ velocity) decrease to less than $45 \%$ due to coal fines dischargement. Thus, coal fines proper production from CBM wells can decrease the permeability loss within coal reservoirs.

\section{Data Availability}

The data used to support the findings of this study are included within the article.

\section{Conflicts of Interest}

The authors declare no competing financial interest.

\section{Acknowledgments}

This study was supported by the National Natural Science Foundation of China (grant no. 41702171); National Science and Technology Major Project of China (no.2017ZX05064003-001 and no.2016ZX05066001-002); Shandong Provincial Key Laboratory of Depositional Mineralization \& Sedimentary Minerals. We thank China United Coalbed Methane Corporation Limited for providing the testing samples.

\section{References}

[1] Z. Sun, J. T. Shi, K. L. Wu, W. Y. Liu, S. R. Wang, and X. F. Li, "A prediction model for desorption area propagation of coalbed methane wells with hydraulic fracturing," Journal of Petroleum Science and Engineering, vol. 175, pp. 286-293, 2019.

[2] W. C. Zhu, J. Liu, T. H. Yang, J. C. Sheng, and D. Elsworth, "Effects of local rock heterogeneities on the hydromechanics of fractured rocks using a digital-image-based technique," International Journal of Rock Mechanics and Mining Sciences, vol. 43, no. 8, pp. 1182-1199, 2006.

[3] Z. Sun, K. Wu, J. Shi et al., "Novel prediction methods for under-saturated coalbed methane wells: Effect of drainage schedules," Journal of Petroleum Science and Engineering, vol. 181, article 106215, 2019.

[4] C. Wei, M. Zou, Y. Sun, Z. Cai, and Y. Qi, "Experimental and applied analyses of particle migration in fractures of coalbed 
methane reservoirs," Journal of Natural Gas Science and Engineering, vol. 23, pp. 399-406, 2015.

[5] Y. Li, Y. B. Wang, J. Wang, and Z. J. Pan, "Variation in permeability during $\mathrm{CO}_{2}-\mathrm{CH}_{4}$ displacement in coal seams: Part 1 Experimental insights," Fuel, vol. 263, article 116666, 2020.

[6] Y. Li, Z. S. Wang, Z. J. Pan, X. L. Niu, Y. Yu, and S. Z. Meng, "Pore structure and its fractal dimensions of transitional shale: A cross- section from east margin of the Ordos Basin, China," Fuel, vol. 241, pp. 417-431, 2019.

[7] S. Liu and S. Harpalani, "Evaluation of in situ stress changes with gas depletion of coalbed methane reservoirs," Journal of Geophysical Research: Solid Earth, vol. 119, no. 8, pp. 62636276, 2014.

[8] D. N. Espinoza, J. M. Pereira, M. Vandamme, P. Dangla, and S. Vidal-Gilbert, "Desorption-induced shear failure of coal bed seams during gas depletion," International Journal of Coal Geology, vol. 137, pp. 142-151.

[9] Y. C. Wei, D. Y. Cao, Y. Yuan et al., "Characteristics of Pulverized coal during coalbed methane drainage in Hancheng block, Shaanxi Province, China," Energy Exploration \& Exploitation, vol. 31, no. 5, pp. 745-757, 2013.

[10] N. Zhang, X. M. Chen, T. Nicholson, and Y. J. Peng, "The effect of froth on the dewatering of coals - An oscillatory rheology study," Fuel, vol. 222, pp. 362-369, 2018.

[11] X. Zhao, S. Liu, S. Sang et al., "Characteristics and generation mechanisms of coal fines in coalbed methane wells in the southern Qinshui Basin, China," Journal of Natural Gas Science and Engineering, vol. 34, pp. 849-863, 2016.

[12] S. Tao, S. Chen, and Z. Pan, "Current status, challenges, and policy suggestions for coalbed methane industry development in China: A review," Energy Science \& Engineering, vol. 7, pp. 1-16, 2019.

[13] Y. Li, J. H. Yang, Z. J. Pan, and W. S. Tong, "Nanoscale pore structure and mechanical property analysis of coal: An insight combining AFM and SEM images," Fuel, vol. 260, article $116352,2020$.

[14] Z. H. Guo, F. Hussain, and Y. Cinar, "Permeability variation associated with fines production from anthracite coal during water injection," International Journal of Coal Geology, vol. 147-148, pp. 46-57, 2015.

[15] C. Zhang, G. Yu, and C. Zhang, "Rock matrix-fractured media model for heterogeneous and fractured coal bed," Transactions of Nonferrous Metals Society of China, vol. 21, pp. S621-S625, 2011.

[16] S. Tao, Z. J. Pan, S. D. Chen, and S. L. Tang, "Coal seam porosity and fracture heterogeneity of marcolithotypes in the Fanzhuang Block, southern Qinshui Basin, China," Journal of Natural Gas Science and Engineering, vol. 66, pp. 148-158, 2019.

[17] J. Pan, Q. Hou, Y. Ju, H. Bai, and Y. Zhao, "Coalbed methane sorption related to coal deformation structures at different temperatures and pressures," Fuel, vol. 102, pp. 760-765, 2012.

[18] Q. Shi, Y. Qin, B. Zhou, M. Zhang, M. Wu, and L. Wang, “An experimental study of the agglomeration of coal fines in suspensions: inspiration for controlling fines in coal reservoirs," Fuel, vol. 211, pp. 110-120, 2018.

[19] S. Torkzaban, S. A. Bradford, J. L. Vanderzalm, B. M. Patterson, B. Harris, and H. Prommer, "Colloid release and clogging in porous media: effects of solution ionic strength and flow velocity," Journal of Contaminant Hydrology, vol. 181, pp. 161-171, 2015.
[20] R. D. Balucan, L. G. Turner, and K. M. Steel, "X-ray $\mu$ CT investigations of the effects of cleat demineralization by $\mathrm{HCl}$ acidizing on coal permeability," Journal of Natural Gas Science and Engineering, vol. 55, pp. 206-218, 2018.

[21] R. X. Rong and J. Hitchins, "Preliminary study of correlations between fine coal characteristics and properties and their dewatering behaviour," Minerals Engineering, vol. 8, no. 3, pp. 293-309, 1995.

[22] G. Han, K. Ling, H. Wu, F. Gao, F. Zhu, and M. Zhang, “An experimental study of coal-fines migration in Coalbedmethane production wells," Journal of Natural Gas Science and Engineering, vol. 26, pp. 1542-1548, 2015.

[23] Z. H. Guo, F. Hussain, and Y. Cinar, "Physical and analytical modelling of permeability damage in bituminous coal caused by fines migration during water production," Journal of Natural Gas Science and Engineering, vol. 35, pp. 331-346, 2016.

[24] T. R. Mitchell and C. R. Leonardi, "Micromechanical investigation of fines liberation and transport during coal seam dewatering," Journal of Natural Gas Science and Engineering, vol. 35, pp. 1101-1120, 2016.

[25] Z. Yao, D. Cao, Y. Wei, X. Li, X. Wang, and X. Zhang, "Experimental analysis on the effect of tectonically deformed coal types on fines generation characteristics," Journal of Petroleum Science and Engineering, vol. 146, pp. 350-359, 2016.

[26] X. Chen and B. Bai, "Experimental investigation and modeling of particulate transportation and deposition in vertical and horizontal flows," Hydrogeology Journal, vol. 23, no. 2, pp. 365-375, 2015.

[27] T. Bai, Z. Chen, S. M. Aminossadati, T. E. Rufford, and L. Liang, "Experimental investigation on the impact of coal fines generation and migration on coal permeability," Journal of Petroleum Science and Engineering, vol. 159, pp. 257-266, 2017.

[28] S. Wang, D. Elsworth, and J. Liu, "Permeability evolution in fractured coal: the roles of fracture geometry and water-content," International Journal of Coal Geology, vol. 87, no. 1, pp. 13-25, 2011.

[29] Y. X. Cao, A. Davis, R. X. Liu, X. Liu, and Y. G. Zhang, "The influence of tectonic deformation on some geochemical properties of coals-a possible indicator of outburst potential," International Journal of Coal Geology, vol. 53, no. 2, pp. 6979, 2003.

[30] S. Tao, S. D. Chen, D. Z. Tang, X. Zhao, H. Xu, and S. Li, "Material composition, pore structure and adsorption capacity of low-rank coals around the first coalification jump: a case of eastern Junggar Basin, China," Fuel, vol. 211, pp. 804-815, 2018.

[31] Y. Meng, D. Tang, H. Xu, C. Li, L. Li, and S. Meng, "Geological controls and coalbed methane production potential evaluation: a case study in Liulin area, eastern Ordos Basin, China," Journal of Natural Gas Science and Engineering., vol. 21, pp. 95-111, 2014.

[32] S. Tao, D. Tang, H. Xu et al., "Fluid velocity sensitivity of coal reservoir and its effect on coalbed methane well productivity: a case of Baode Block, northeastern Ordos Basin, China," Journal of Petroleum Science and Engineering, vol. 152, pp. 229-237, 2017.

[33] S. Liu and S. Harpalani, "Determination of the effective stress law for deformation in coalbed methane reservoirs," Rock Mechanics and Rock Engineering, vol. 47, no. 5, pp. 18091820, 2014. 
[34] Z. Pan and L. D. Connell, "Modelling permeability for coal reservoirs: a review of analytical models and testing data," International Journal of Coal Geology, vol. 92, pp. 1-44, 2012.

[35] Y. S. Zou, S. C. Zhang, and J. Zhang, "Experimental method to simulate coal fines migration and coal fines aggregation prevention in the hydraulic fracture," Transport in Porous Media, vol. 101, no. 1, pp. 17-34, 2014.

[36] J. Zou, W. Chen, D. Yang, H. Yu, and J. Yuan, "The impact of effective stress and gas slippage on coal permeability under cyclic loading," Journal of Natural Gas Science and Engineering, vol. 31, pp. 236-248, 2016.

[37] X. J. Fei, Slurry and granular material transport hydraulics, Tsinghua University Press, 1994.

[38] Z. Pan, L. D. Connell, and M. Camilleri, "Laboratory characterisation of coal reservoir permeability for primary and enhanced coalbed methane recovery," International Journal of Coal Geology, vol. 82, no. 3-4, pp. 252-261, 2010.

[39] J. L. Zhao, D. Z. Tang, W. J. Lin, H. Xu, Y. Li, and S. Tao, "Permeability dynamic variation under the action of stress in the medium and high rank coal reservoir," Journal of Natural Gas Science and Engineering, vol. 26, pp. 1030-1041, 2015.

[40] C. Gruesbeck and R. E. Collins, "Entrainment and deposition of fine particles in porous media," Journal of Petroleum Science and Engineering, vol. 22, pp. 847-856, 1982.

[41] G. A. Gabriel and G. R. Inamdar, "An Experimental Investigation of Fines Migration in Porous Media," in SPE Annual Technical Conference and Exhibition, San Francisco, CA, USA, 1983.

[42] S. B. Roy and D. A. Dzombak, "Colloid release and transport processes in natural and model porous media," Colloids and Surfaces A: Physicochemical and Engineering Aspects, vol. 107, pp. 245-262, 1996.

[43] D. Gao, Y. Liu, T. Wang et al., "Experimental investigation of the impact of coal fines migration on coal Core water flooding," Sustainability, vol. 10, no. 11, article 4102, 2018.

[44] F. S. Han, A. Busch, B. M. Krooss, Z. Y. Liu, N. V. Wageningen, and J. L. Yang, "Experimental study on fluid transport processes in the cleat and matrix systems of coal," Energy \& Fuels, vol. 24 , no. 12 , pp. 6653-6661, 2010.

[45] F. S. Han, A. Busch, N. V. Wageningen, J. L. Yang, Z. Y. Liu, and B. M. Krooss, "Experimental study of gas and water transport processes in the inter-cleat (matrix) system of coal: anthracite from Qinshui Basin, China," International Journal of Coal Geology, vol. 81, no. 2, pp. 128-138, 2010.

[46] D. P. Magill, M. Ramurthy, R. Jordan, and P. D. Nguyen, "Controlling coal-fines production in massively cavitated openhole coalbed-methane wells," in SPE Asia Pacific Oil and Gas Conference and Exhibition, Brisbane, Australia, 2010. 